\title{
Transformation of different reaches of the Niida River (Japan) after extreme flood
}

\author{
Valentin GOLOSOV ${ }^{1 *}$, Dmitry BOTAVIN ${ }^{1}$, Alexei KONOPLEV ${ }^{2}$, Yoshifumi WAKIYAMA ${ }^{2}$ \\ ${ }^{1}$ Faculty of Geography, Lomonosov Moscow State University, Moscow, Russia \\ 2 Institute of Environmental Radioactivity, Fukushima University, Fukushima, Japan \\ Received 15 October 2017; Revised 30 October 2017; Accepted 15 November 2017 \\ *Correspondence to: Valentin GOLOSOV, e-mail: gollossov@gmail.com
}

\begin{abstract}
Extreme floods can have different effects on the river bottom relief depending on several factors. The geomorphological impact of the extreme flood occurring in the Niida River basin (Fukushima prefecture, Honshu inland, Japan) on the channels and river bottom of different reaches of the river is analyzed. High-resolution satellite images and field assessments were used for quantitative evaluation of river bottom transformation which mainly occurred in the lower reach of the Niida river. The lower reach of the Niida River was divided on three subzones according the channel gradient changes. Each sub-zones is correspond with the dominance of a certain type of channel (straight, meandering and wandering). It was found that bank erosion exceeded in- channel deposition in 1,7-2,7 times for all types of river channel in the low reach located within the coastal floodplain. However, floodplain sedimentation is the most active processes for the river sections with meandering and wandering types of the river channel. Floodplain sedimentation exceed bank-erosion in 2.2 times for river sections with the meandering type of channel and in 2.9 time for the river sections with wandering type of channel. It was found that bank erosion exceeded in- channel deposition in 1,7-2,7 times for all types of river channel in the low reach located within the coastal floodplain. However, floodplain sedimentation is the most active processes for the river sections with meandering and wandering types of the river channel. Floodplain sedimentation exceed bankerosion in 2.2 times for river sections with the meandering type of channel and in 2.9 time for the river sections with wandering type of channel. The bank erosion exceeds floodplain deposition in 1,2 times only within the river sections with straight type of channel. Total sedimentation (in-channel + floodplain) in 2.6 times higher than bank erosion in the lower reach of the Niida River after extreme flood event with probability $4-5 \%$.
\end{abstract}

KEYWORDS

Bank erosion; sedimentation; Niida river; valley bottom transformation 


\section{Introduction}

Small mountainous rivers are characterized by high dynamics of river channel transformation due to high frequency of extreme floods. It is particularly true for small rivers of the sub-tropic and tropic landscape zones with high amount of annual precipitation exceeding $1000 \mathrm{~mm}$ per year. As a result, serious transformation of different river reaches occurs depending on water and sediment discharges and channel stability. Extreme flood events are very typical of small mountainous river basins in different parts of tropical and sub-tropical landscape zones (Marchi et al., 2010; Borga et al., 2014). They usually result in both intense erosion and sediment deposition on the river valley bottom (Costa, 1988; Gaume and Borga, 2008). Also, sedimentation rates considerably influence alluvial soil formation, depending on the sources of sediment. The consequences of extreme flood events are usually studied for the following calculations of stability of different constructions within the river valleys.

Geomorphic consequences of a flood can be evaluated based on the amount of sediment transported and also the amount of channel and floodplain morphological change caused by the flood (Wolman and Miller, 1960; Wolman and Gerson, 1978; Rădoane et al, 2013). All this depends on flood strength, river bottom morphology, sediment composition, and reach connectivity (Hooke, 2003). In most cases it isn't possible to measure the amount of sediment transported during an extreme flood, because any measurement equipment would be damaged and destroyed. Therefore, it is only morphological analysis of the river channel and floodplain transformation after an event that can be used for quantification of geomorphic consequences.

Different methods and approaches are used for the evaluation of river channel and bottom transformation, including direct measurements of the river bottom morphology, application of aerial and satellite images interpretations (Zanoni et al., 2008; Surian et al., 2009; Lane et al.,2003). Most detailed study can also be done using laser scanning (Kuo et al., 2015). Large or extreme floods may influence the river bottom morphology in different ways depending on the local features of the particular reach (Kochel, 1988; Eaton \& Lapointe,2001; Fuller, 2008; Thompson \& Croke, 2013).

A detailed study of geomorphological impact of extreme flood on the morphology of different sections of the river valley bottom was undertaken in the Niida River basin (Fukushima Prefecture). An extreme flood event had occurred in the middle of September 2015, when 385-456 mm of precipitation fell during 6 days with maximum $200 \mathrm{~mm} /$ day in the end of the typhoon.

The objective of the study is evaluating the erosion/deposition processes and their spatial changes in different reaches of the Niida river, with particular attention to the low reach of the Niida River.

\section{Study area}

The study was conducted in the Niida River basin, which is one of several small river basins of the Fukushima Prefecture affected by serious radionuclide contamination after the FDNPP accident (Fig. 1). The total basin area is $265 \mathrm{~km}^{2}$ and the elevation ranges from 0 to about $850 \mathrm{~m}$ ASL. The mean annual water discharges of the Niida River in the lower reach changes from the year to year depending from the amount of precipitation within the range 8-15 $\mathrm{m}^{3} \mathrm{sec}^{-1}$ (Fukushima...,2007). Maximum water discharges $\left(100-200 \mathrm{~m}^{3} \mathrm{sec}^{-1}\right)$ are observed during typhoon season. The Niida basin is characterized by wet monsoon climate with highly variable total annual precipitation. According the meteorological observation the mean annual precipitation is $1900 \mathrm{~mm}$ at Haramachi station in the downstream reaches and $1700-1800 \mathrm{~mm}$ at litate and Tsushima stations located in the upper part of basin (JMA, 2016). Less than $5-7 \%$ of precipitation falls as snow. Extreme rains with precipitation sum $>200 \mathrm{~mm}$ and $>100 \mathrm{~mm}$ per event occur once every 5-7 years and every 1.5 years, respectively, according to meteorological observations. Several rains $>50 \mathrm{~mm}$ fall each year, most frequently during 
the monsoon season between June and September. Some heavy rains can, however, occur in April-May, when soil surface on cultivated fields is less protected by vegetation. Soils of steep slopes are shallow with high organic content. They are characterized by high permeability with intensive subsurface flow leading to tunnel erosion. Soils of the upland depressions and coastal lowlands are considerably transformed because of the agricultural activities. According to the erosion model calculation, despite the low topographic ranges and gradients, soil loss from cultivated fields is the main source of suspended sediment in small rivers of the coastal zones Fukushima Prefecture (Kitamura et al., 2014).

Three main geomorphic regions have been selected within the Niida River basin (see Fig.1): 1) moderately dissected uplands, including low mountains and depressions, dominated by plutonic rocks (mostly Cretaceous granites and granodiorites); 2) severely dissected rangelands of the intensive faulting zone with a very complex geological structure consisting of patchwork of magmatic (both intrusive and effusive) and metamorphic (gneiss and schist) rocks; 3) coastal lowlands dominated by Tertiary to Quaternary terrestrial and marine sedimentary rocks, with low topographic ranges and gradients.

The main orographic elements of uplands that occupy the upper (western most) part of the basin are low mountains and hills with relative elevation 200-350 m and moderate to steep slopes and wide flat-bottomed depressions occupied by main stream valleys. Hills are dissected by numerous gullies and small valleys with ephemeral and perennial streams and relatively short $(100-200 \mathrm{~m})$ slopes mostly covered by forest. This network is the main pathway for sediment transport from hills into main valleys in depressions. Limited areas of lower parts of hillslopes were artificially terraced to be used for cultivation. Most of depressions bottoms areas are used as paddy fields. Channels of main streams have high to moderate gradients and dominantly mixed gravel to coarse sand alluvium. Channels of the main streams and lower parts of their tributaries that drain depressions are mostly artificially canalized, with concrete embankments along straightened sections and systems of regulated flow gates on tributaries for paddy irrigation (Fig.2A). Both natural conditions (widened floodplains within depressions) and human impact (canalization, paddy fields) determine the potential for some fluvial sediment storage in this part of the basin.

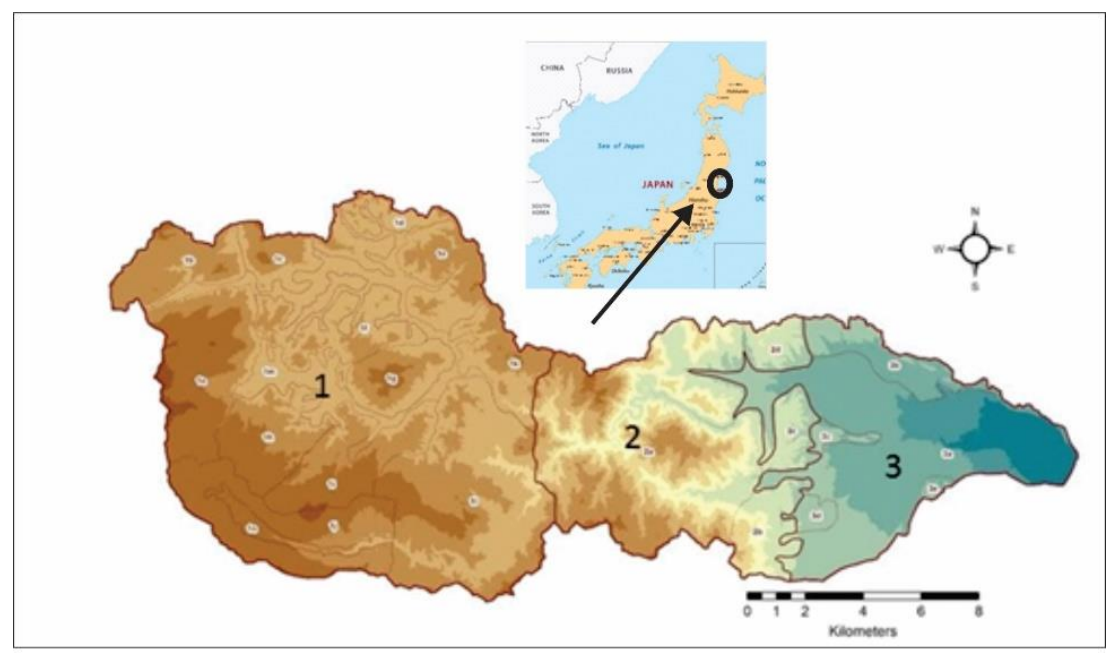

Figure 1 Geomorphic regions of the Niida River basin and location of Niida River basin within Japan (1-3 are the geomorphic regions).

Coastal lowlands are characterized by very flat topography with low ranges and gradients except some peripheral residual hills. This area is mostly occupied by agriculture, settlements and 
infrastructure. River channels have substantially lower gradients and are also artificially modified here by construction of low-level flow regulation dams and flood-protection levees on top of one or both channel banks. The most part of channel sections have also been artificially canalized by concrete banks (Fig.2C).

Different types of the river channels depending on the degree of anthropogenic impact can be distinguished in the Niida River basin. Artificially canalized channels with concrete embankments and levees are the dominant type for main rivers draining the basin headwaters upland depressions (Fig.2A). Constantly increasing volume of sediment deposited within a concrete channel effectively reduces the active cross-section area of a stream. As a result, the frequency of middle floodplain inundation increases considerably as compared with natural floodplain cross-sections. The second type of channels is mostly typical for the coastal lowlands of the Niida River basin. It is represented by significantly wider channels with flood-protection levees on one (if one bank is naturally steep) or two sides, as well as low-level dams used mostly for irrigation needs (Fig. 2C). Rangelands of the faulting zone occupy middle reaches of the main river and its tributaries in central part of the Niida River basin. The density of gully and small valley network is higher than that of the uplands. Slopes of that area have high to very high gradients.
Both small tributaries and main river channels in this area are characterized by very high gradients and composed mostly of cobbles and boulders with bedrock outcrops. Channels retain natural morphology without human interference. It can therefore be suggested that there is high hydrological and geomorphic connectivity between the catchment slopes, small tributaries and main river channels in this part of the basin.

Some valley reaches within uplands depression also have wider channels, but unconfined by levees or embankments (though there can be levees on one or both sides, but remote from the channel along the higher floodplain or low terrace level) and without low-level dams. Usually three levels of floodplain can be identified in such valley bottoms. In some cases, however it is difficult to distinguish low and middle floodplains. Natural step-and-pool channels dominated by cobble-boulder alluvium and bedrock is the third type of river channel dominant within the rangelands area (Fig.2B). The gradient of such channels is much higher than those of all other types, and very often floodplain is totally absent. Sometimes fragments of high or very young low floodplain can be identified. River reaches with bedrock channels are characterized by extremely limited amount of floodplain sediment deposition except for certain specific locations such as young point bar surface.

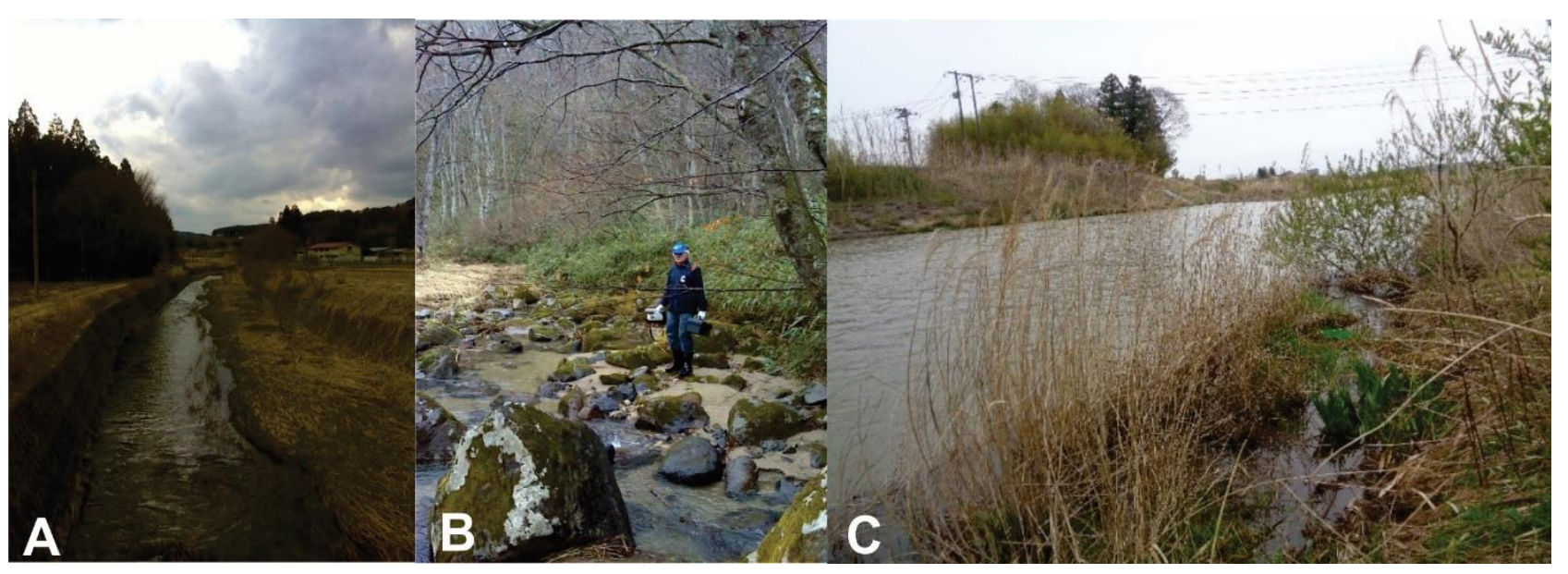

Figure 2 Views of the Niida river channels in the different geomorphic regions: A - upper reach, depression in uplands; B - middle reach, severely dissected rangelands; C - lower reach, coastal lowland 


\section{Material and methods}

A extreme flood with $4-5 \%$ annual exceedance probability occurred from 6 to 11 September 2015 as a result of Tropical Storm Etau (Golosov et al., 2016). During a 6 days-period, $456 \mathrm{~mm}$ of precipitation fell in the upper reach of Niida River (according to JMA data for Iitate meteorological station) which is about one fouth of the annual norm. Maximum rainfall with $200 \mathrm{~mm}$ precipitation was observed on the last day. All measurement equipment was destroyed, so actual maximum water discharges unknown. Preliminary assessment of water discharge for the some cross-sections in the low reach was evaluated based on heights under floodplain of objects dangling on trees. It is more likely that maximum water discharge during this extreme event was about $220-250 \mathrm{~m}^{3} \mathrm{sec}^{-1}$. During the flood of September 2015, water flows washed out the unsupported sections of stream banks. Also, some landslides occurred, mainly on very steep slopes.

The geomorphological impact of the extreme flood was identified in all reaches of the Niida River basins during the field survey. The most considerable changes were seen within the lower reach in the coastal lowland of the Niida River. So, the most detailed study was done for this reach which is located between the foothills and ocean coast. To assess the geomorphic impacts of the floods on the Niida channel and floodplain, high resolution satellite images of a $14-\mathrm{km}$-long lower reach of the Niida were taken from Google Earth on 1 June 2015 and 12 November 2015, which were made before and after extreme flooding. Images were orthorectified and georeferenced using ERSI ArcGIS in geodatabase format. Channel changes were identified from the photography and verified using field visits at selected sites. By on-screen digitizing a series of metric polygons were generated for the entire $14-\mathrm{km}$ reach, identifying wetted channel, bars, active channel (wetted channel and bars combined) and areas of inundation (proximal to the channel) and bank erosion. Proximal inundation is defined as that adjacent to the channel, identifiable by thick drapes of sediment over the floodplain overlaying previously vegetated or partly vegetated section of floodplain. Distal inundation is that further away from the channel with shallow layer of fresh fine sediment were not taken into consideration, because it was difficult to identify them on the satellite image.

Then the lower reach of the Niida River was divided into 21 sections according morphology of channels (Fig.3). There are few river channel type classifications used in the scientific literature. In Russian geomorphology three main morphological types of the river channel are usually selected: straight, braided and meandering (Leopold \& Wolman, 1957; Alabyan \& Chalov, 1998).

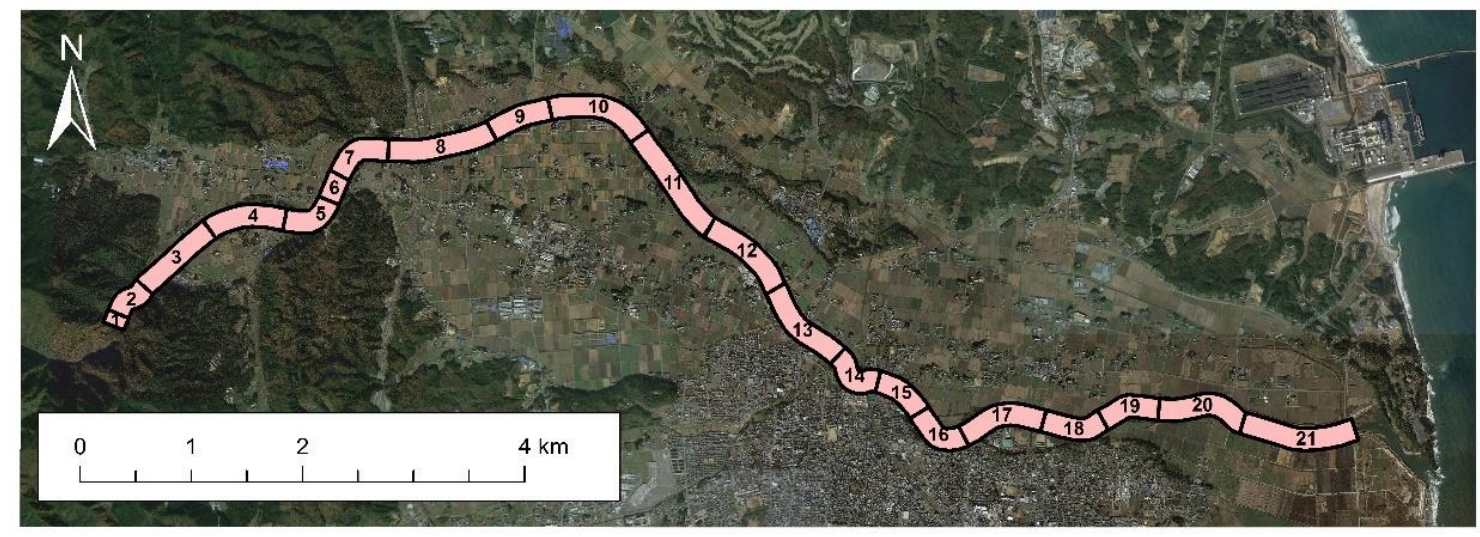

Figure 3 Location of the studied sections of the lower reach of the Niida River

However, classification of the river channels suggested by Schumm (1985) is more appropriated for the Niida River, because it is included intermediate types of the river channels. One of 
them is wandering type of river channel. Wandering rivers have a morphology that is intermediate between braiding and meandering with multiple channels separated by islands. So, river channels within each section were described using both Schumm and Leopold \& Wolman classification. On the next stage the entire $14-\mathrm{km}$ reach was divided into three sub-zones depending on the bed-slope gradients according to the classification suggested by Chalov (1996): sub-zone 1 (semi-mountainous); sub-zone 2 (semi-mountainous - plain) and subzone 3 (plain).

Areas of bank erosion and in-channel deposition was determined for each section (Table 1, Fig.4). Also, area of fresh sedimentation on floodplain was evaluated based on overlapping of vegetation by sediments Field verification of the results of satellite image interpretation was undertaken along several profiles for typical sections belonging to each type of the channel (Fig.4). The correctness of identification of the boundaries of different areas was within $\pm 2 \mathrm{~m}$. In addition, direct measurements of sedimentation for the extreme event was done along the same profiles, using a metal stick and tape-measure.
Depth of fresh sediments can be easily identified on the grassed floodplain section. However, it did not seem possible to perform reasonably correct measurement of fresh sediment depth within the bars unprotected by vegetation. So, we took the decision to analyze only the spatial changes of the river valley bottom without using volumetric measurements because of very high differences in correctness of spatial measurements and depth evaluation.

Evaluation of the geomorphological impact of the extreme flood on the river channels and floodplains in the two other geomorphological zones of the Niida River basin (see Fig.1) was based on the semi-quantitative assessment of the modification of typical fragments of the river valley bottoms. Sedimentation rates on the different floodplain level was measured using a metal stick or small pits (in case of extremely high deposition) and tape-measure. It wasn't possible to use satellite image interpretation for evaluation of the channel modification because of two reasons. Firstly, in the most cases the bank erosion and in-channel deposition rates don't exceed $1 \mathrm{~m}$. Secondly, very often the river banks were covered by trees.

Table 1 Mean areas of the Niida river valley bottom affected by bank erosion, in-channel deposition and intensive overbank sedimentation within individual sections

\begin{tabular}{|c|c|c|c|c|c|c|c|c|}
\hline $\begin{array}{c}\text { River } \\
\text { section }\end{array}$ & Type of channel & $\mathbf{E}_{\mathrm{b}}{ }^{*}$ & $\mathbf{D}_{\mathrm{ch}}$ & $\mathbf{D}_{\mathbf{f}}$ & $\begin{array}{l}\text { Length } \\
\text { (L), m }\end{array}$ & $\begin{array}{l}\text { Wavelength } \\
\text { (I), m }\end{array}$ & $(\mathrm{L} / \mathrm{I})$ & $\begin{array}{c}\text { Average } \\
\text { height, m } \\
\text { a.s.l. }\end{array}$ \\
\hline \multicolumn{9}{|c|}{ semi-mountainous sub-zone (average slope $8 \%$ ) } \\
\hline 1 & straight & 524 & 93 & 2323 & 122 & 122 & 1,00 & 65 \\
\hline 2 & meandering & 1075 & 153 & 6499 & 360 & 341 & 1,06 & 60 \\
\hline 3 & $\begin{array}{c}\text { straight } \\
\text { wandering }\end{array}$ & 5917 & 696 & 2715 & 780 & 780 & 1,00 & 55 \\
\hline 4 & (braided) & 9897 & 488 & 15691 & 702 & 684 & 1,03 & 48 \\
\hline 5 & $\begin{array}{c}\text { meandering } \\
\text { wandering }\end{array}$ & 4655 & 4133 & 12227 & 508 & 431 & 1,18 & 45 \\
\hline 6 & (braided) & 3331 & 120 & 5924 & 248 & 248 & 1,00 & 43 \\
\hline 7 & meandering & 11002 & 2892 & 14244 & 592 & 502 & 1,18 & 38 \\
\hline 8 & straight & 8542 & 407 & 2856 & 956 & 945 & 1,01 & 35 \\
\hline \multicolumn{9}{|c|}{ transit from semi-mountainous to plain sub-zone (average slope 4\%o) } \\
\hline 9 & straight & 4954 & 1248 & 9911 & 577 & 565 & 1,02 & 30 \\
\hline 10 & $\begin{array}{c}\text { meandering } \\
\text { wandering }\end{array}$ & 10315 & 3517 & 22359 & 906 & 851 & 1,06 & 25 \\
\hline 11 & (braided) & 10691 & 2290 & 19523 & 1041 & 1041 & 1,00 & 20 \\
\hline
\end{tabular}


Transformation of different reaches of the Niida River (Japan) after extreme flood

\begin{tabular}{|c|c|c|c|c|c|c|c|c|}
\hline 12 & meandering & 8429 & 772 & 23427 & 859 & 808 & 1,06 & 18 \\
\hline 13 & meandering & 8757 & 6237 & 22424 & 866 & 824 & 1,05 & 16 \\
\hline 14 & meandering & 3976 & 1370 & 1378 & 500 & 427 & 1,17 & 13 \\
\hline \multicolumn{9}{|c|}{ plain sub-zone (average slope 3\%o) } \\
\hline 15 & $\begin{array}{l}\text { wandering } \\
\text { (braided) }\end{array}$ & 452 & 11152 & 15647 & 483 & 466 & 1,04 & 12 \\
\hline 16 & $\begin{array}{l}\text { meandering } \\
\text { wandering }\end{array}$ & 4872 & 1351 & 10269 & 520 & 449 & 1,16 & 10 \\
\hline 17 & $\begin{array}{l}\text { (braided) } \\
\text { wandering }\end{array}$ & 4241 & 3583 & 12968 & 776 & 722 & 1,07 & 8 \\
\hline 18 & (braided) & 4202 & 1367 & 18960 & 589 & 542 & 1,09 & 6 \\
\hline 19 & $\begin{array}{l}\text { meandering } \\
\text { wandering }\end{array}$ & 2601 & 324 & 8507 & 540 & 513 & 1,05 & 4 \\
\hline 20 & (braided) & 5667 & 3611 & 23935 & 839 & 764 & 1,10 & 2 \\
\hline 21 & straight & 3232 & 369 & 644 & 1041 & 1011 & 1,03 & 1 \\
\hline
\end{tabular}

${ }^{*} E_{b}$ - bank erosion, $m^{2} ; D_{c h}$ - in channel deposition, $m^{2} ; D_{f}$ - floodplain sedimentation, $m^{2}$

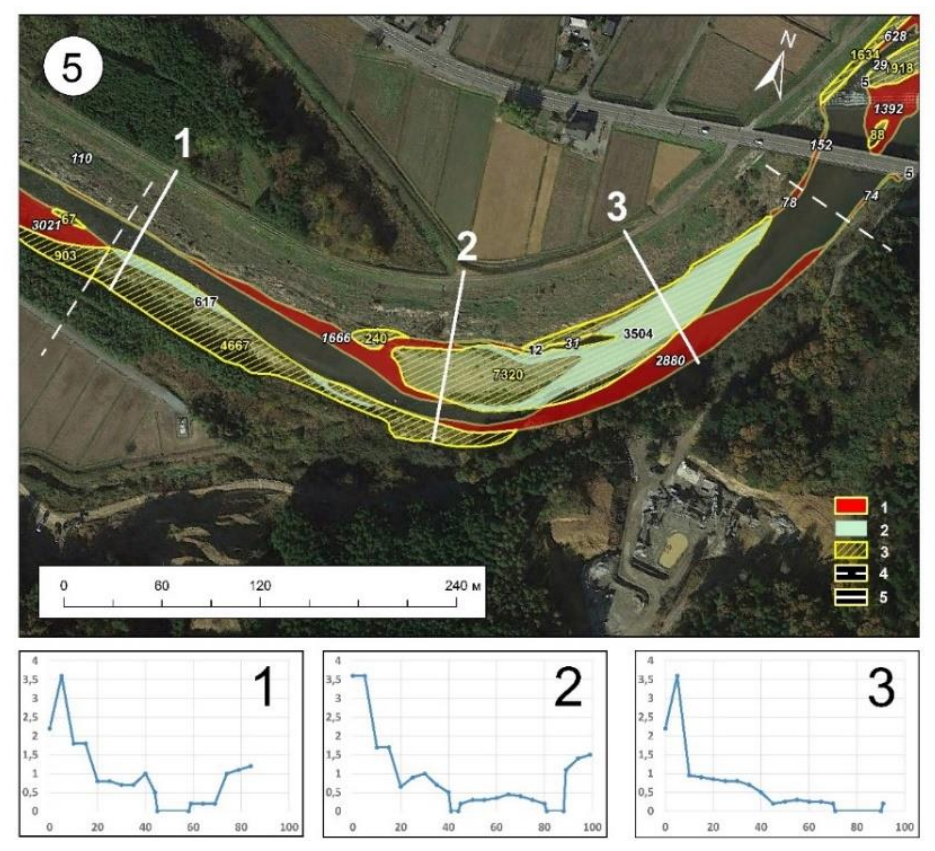

Figure 4 Section 5, sub-zone 1 of the lower reach of the Niida River. Legend: 1- areas of erosion; 2 - areas of in channel deposition; 3 - areas of floodplain sedimentation; 4 - boundary of section; 5 - field cross-section profile locations. Below - cross-section profiles, constructed based on the field measurements.

\section{Results and discussion}

The proportion of different type channel changes along the lower reach of the Niida river according to decreasing of the river bed gradients towards the river mouth (Table 2). In the upper-most sub-zone with the highest mean river bed gradient the straight channel dominated. In the sub-zone two the proportion of meandering channel is as high as $66 \%$. In the sub-zone 3 , located near the river mouth and partly affected in the lowest section by tidal regime the braided channel type became the most extended. It should be reminded that several low-level dams are located along the entire lower reach of the Niida River (see as an example, view of such dam in right high corner of Figure 3 ). It is undoubtedly influenced the river bed gradient, and it is another reason of the presence of wandering (braided) type channels in sub-zones 1 and 2. 
Table 2 Distribution of channel types in different sub-zones of the lower reach of the Niida River Type of channel

Length, $\mathbf{m}$ and proportion of different channel types

\begin{tabular}{lcccc}
\cline { 2 - 4 } & Sub-zone 1 & Sub-zone 2 & Sub-zone 3 & Total \\
\hline Straight & $1868 / 44 \%$ & $577 / 12 \%$ & $1041 / 22 \%$ & $3486 / 25 \%$ \\
Meandering & $1460 / 34 \%$ & $3131 / 66 \%$ & $1060 / 22 \%$ & $5651 / 41 \%$ \\
Wandering (Braided) & $950 / 22 \%$ & $1041 / 22 \%$ & $2687 / 56 \%$ & $4678 / 34 \%$ \\
Total & $4268 / 100 \%$ & $4749 / 100 \%$ & 4778 & 13795 \\
\hline
\end{tabular}

The width of the valley bottom of the Niida River is relatively stable along the lower reach, changing within the range $90-110 \mathrm{~m}$ (Fig.4). So, the it is possible to use the length of type of channel for calculation of specific area of the different erosiondepositional processes (Table 3), which actually characterized the proportion of erosion and sedimentation within the different parts of the river valley bottom, including the river channel and floodplain. The river section with straight type of channel is characterized by almost zero budget with extremely low in-channel deposition and the lowest bank erosion and floodplain sedimentation (Table 3).

Table 3 Specific area of bank erosion, in channel deposition and floodplain sedimentation for the sections of lower reach of the Niida river with different channel types.

\begin{tabular}{lccc}
\hline Type of channel & $\begin{array}{c}\text { Specific area of bank } \\
\text { erosion, } \mathbf{~}^{\mathbf{2}} \mathbf{~} \mathbf{m}\end{array}$ & $\begin{array}{c}\text { Specific area of in -channel } \\
\text { deposition, } \mathbf{~}^{\mathbf{2}} \mathbf{~} \mathbf{m}\end{array}$ & $\begin{array}{c}\text { Specific area of floodplain } \\
\text { sedimentation, } \mathbf{~}^{\mathbf{2}} / \mathbf{m}\end{array}$ \\
\hline Straight & 6.6 & 0.8 & 5.3 \\
Meandering & 9.9 & 3.7 & 21.5 \\
Wandering & 8.2 & 4.8 & 24.0 \\
(Braided) & & 3.3 & 18.3 \\
Total & 8.5 & & \\
\hline
\end{tabular}

While both sections with meandering and wandering (braided) types of channels are characterized by high floodplain sedimentation during the extreme flood, the bank erosion exceeds the in-channel deposition by 1.7-2.7 times.

The proportion of areas with bank erosion and different types of sedimentation change differently for the different types of river channel in direction from foothills to the river mouth (Table 4). In the case of wandering (braided) channels, the proportion of deposition is increasing from subzone 1 to sub-zone 3 . The bank erosion exceeds the total sedimentation in the case of straight channel. The highest proportion of sedimentation is observed for the meandering channels with extremely large deposition in sub-section 3 (Table 4).

However, the highest bank erosion is observed for the meandering rivers. It is important to underline that areas of bank erosion exceed the area with in-channel deposition for all types of channel and for all sub-zones, excluding only meandering channel in sub-zone 3 . It is fair to assume that river channel incision and intensive floodplain sedimentation were the dominant processes in the lower reach of the Niida River during the extreme flood. Extremely high energy of the stream has been confirmed by intensive bank erosion even in sub-zone 3 (Fig. 5). 
Table 4 Mean areas of the lower reach of the Niida river valley bottom affected by bank erosion, in-channel deposition and intensive overbank sedimentation

\begin{tabular}{|c|c|c|c|c|}
\hline Type of channel & $E_{b}{ }^{*}$ & $\mathbf{D}_{\mathrm{ch}}$ & $D_{f}$ & $\begin{array}{c}\text { Proportion } \\
D_{c h}+D_{f} / E_{b}\end{array}$ \\
\hline \multicolumn{5}{|c|}{ Sub-zone 1 (semi-mountainous) ** } \\
\hline Meandering & 16732 & 7178 & 32970 & 2.4 \\
\hline Wandering & & & & 1.8 \\
\hline (Braided) & 13228 & 608 & 21615 & \\
\hline Straight & 14983 & 1196 & 7894 & 0.6 \\
\hline Sub-total & 44943 & 8982 & 62479 & 1.6 \\
\hline \multicolumn{5}{|c|}{ Sub-zone 2 (transit from semi-mountainous to plain sub-zone) } \\
\hline Meandering & 31447 & 11896 & 69588 & 2.6 \\
\hline $\begin{array}{l}\text { Wandering } \\
\text { (Braided) }\end{array}$ & 10691 & 2290 & 19523 & 2.0 \\
\hline Straight & 4954 & 1248 & 9911 & 2.2 \\
\hline Sub-total & 47122 & 15434 & 99022 & 2.4 \\
\hline \multicolumn{5}{|c|}{ Sub-zone 3 (plain sub-zone) } \\
\hline Meandering & 14562 & 19713 & 71510 & 6.2 \\
\hline $\begin{array}{l}\text { Wandering } \\
\text { (Braided) }\end{array}$ & 7473 & 1675 & 18776 & 2.7 \\
\hline Straight & 3232 & 369 & 644 & 0.3 \\
\hline Sub-total & 25267 & 21757 & 90930 & 4.5 \\
\hline Total & 113822 & 46173 & 252331 & 2.6 \\
\hline
\end{tabular}

${ }^{*} E_{b}$ - bank erosion, $m^{2} ; D_{c h}-$ in-channel deposition, $m^{2} ; D_{f}-$ floodplain sedimentation, $m^{2}$

** sub-zone of the river valley bottom of the lower reach were separated according to the decrease of the river-bed gradient towards the mouth.

It was established that bank erosion is particularly high in sub-zone 1 because of high energy of the flow after the exit of the Niida river from the mountains to the coastal plain, in particular, in the river reaches with straight type of channel. Generally, erosion dominated over inchannel deposition for all sub-zones of the lower reach of the Niida River except meandering channel type at section 3. However, the meandering type of channel is characterized by the relationship of relative equilibrium between erosion and in-channel deposition even at section 1 with the most active valley bottom transformation, including overbank sedimentation.

The wandering (braided) type of the river channel is characterized by different modification of the river valley bottom depending on the river channel gradient. Active erosion was identified for the wandering (braided) channel at the sub-zone 1, section 6 (Fig.6), while intensive in-channel deposition was observed at the sub-zone 3 , section 15 (Fig.7).

Results of the field survey were used for understanding of the effect of extreme flood on river channels and floodplains in other reaches of the Niida river. The transformation of upper reaches of the Niida River within intermountain depressions depends on the type of the channel. High sedimentation on the floodplain in the range 10-15 $\mathrm{cm}$ (one order of magnitude higher than the mean annual) is typical for the artificially canalized channels with concrete embankments and levees, which are the dominant type for main rivers draining the basin headwaters upland depressions. However, sedimentation rates in only $1-3 \mathrm{~cm}$ was established after extreme flood for the uppermost section of the artificially canalized channels. Some valley reaches within uplands depression have wider channels, but unconfined by levees or embankments (though there can be levees on one or both sides, but remote from the channel along 
the higher floodplain or low terrace level). Here in some sections within the floodplain there was extremely high deposition of sand and pebble material with an average depth of $30-40 \mathrm{~cm}$ and a total weight of 400-500 tons. Usually extremely high sedimentation was associated with very active bank erosion upstream of such sections.

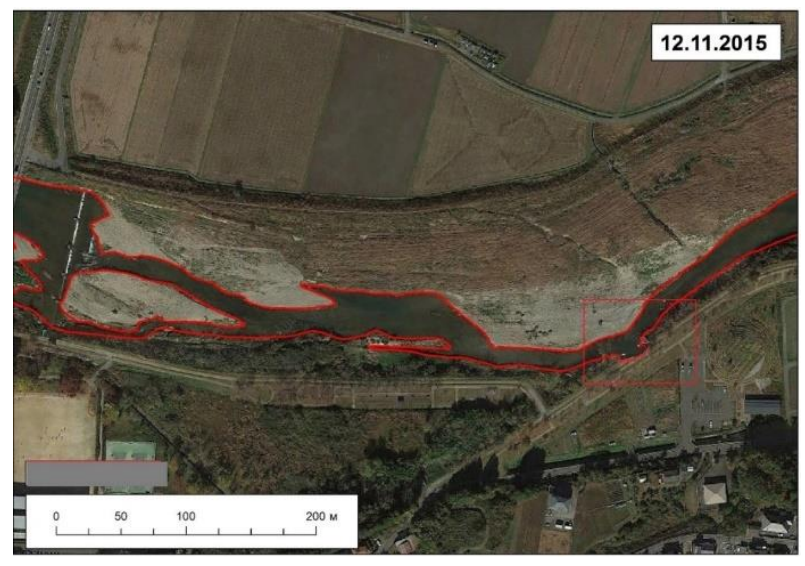

A

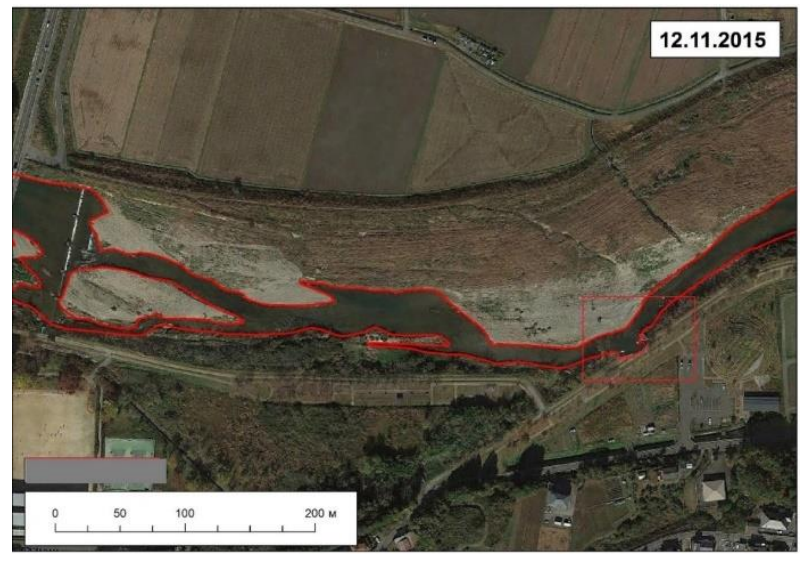

B

Figure 5 Section 18 (sub-zone 3) of the lower reach of the Niida River before (A) and after (B) extreme flood. Legend: 1 - eroded part of the bank of the Niida River protected by concrete embankments; river channel position before extreme flood, 01.06.2015; 3 - river channel position after extreme flood, 12.11.2015. As can be seen the road on the right bank is completely washed out

As a result, it is possible to subdivide different parts of the Niida River basin schematically represented by the respective longitudinal profile reaches according to the main processes influencing sediment redistribution (Fig. 8).
Hills within the basin headwaters uplands are one of the dominant sediment sources during extreme events. Based on the monitoring results (Ueda et al., 2013), it is fair to suggest that bank and, possibly, small stream bed erosion are the main sources of sediments, with mass movement processes (creep, shallow landslides) being the secondary sources. It is very likely that sheet and rill erosion occur under the forest during extreme flood.

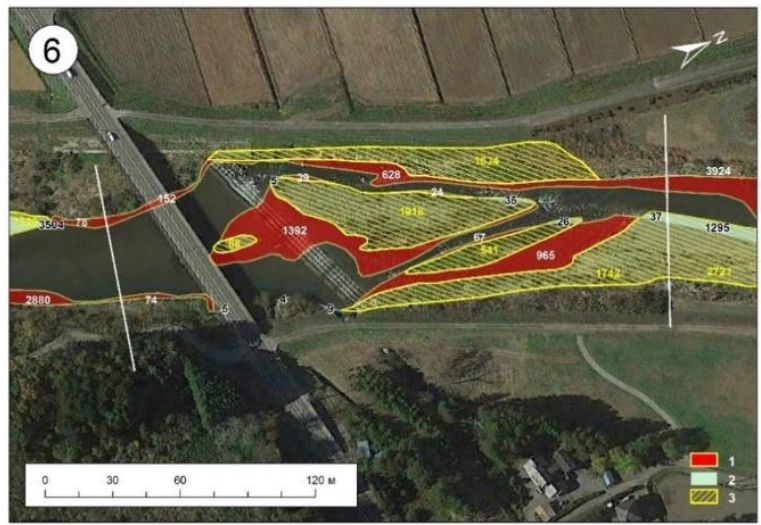

Figure 6 The bank erosion (1), in channel deposition (2) and floodplain sedimentation (3) zones appeared after extreme flood at the section 1 (sub-zone 1, semimountainous sub-reach) within the wandering (braiding) type of the Niida River channel

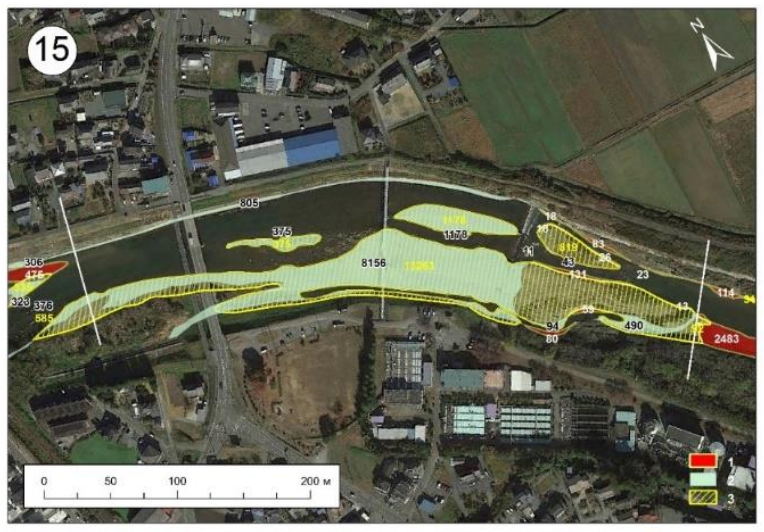

Figure 7 The bank erosion (1), in channel deposition (2) and floodplain sedimentation (3) zones formed after extreme flood at the section 3 (plain sub-reach) within the wandering (braided) type of the Niida River channel.

According to the monitoring data, overland flow on forested hillslopes is formed only during 
extremely heavy rainstorms or locally at spots unprotected by litter and understory vegetation (Miyata et al., 2009). Runoff coefficient decreases with increase of slope catchment area and was found to be less than 0.05 on $20 \mathrm{~m}$ along forested slope (Gomi et al., 2008). Serious soil loss in subtropical forested catchment (Honshu Island) with total annual precipitation about $3500 \mathrm{~mm}$ is observed only during extreme rainstorms with precipitation sum $>300 \mathrm{~mm}$ per event according to the field monitoring (Fukuyama et al., 2005). Such rains are very unusual for the river basins of the northeastern part of the Honshu Island with annual precipitation of $1200-1800 \mathrm{~mm}$ only.

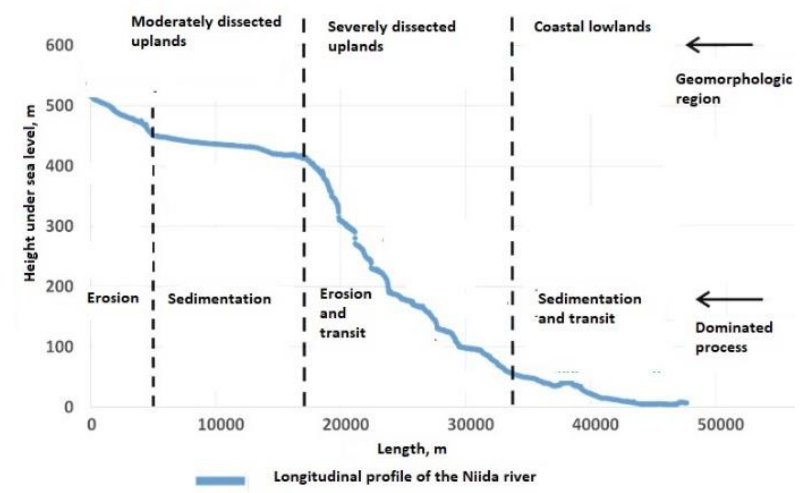

Figure 8 Longitudinal profile of the Niida river

Small streams are the main transportation pathways delivering sediments from the steep forested hillslope areas. For example, results of monitoring of water and sediment discharge in small stream catchment of the Japanese Alps demonstrate that maximum sediment amounts are transported during snowmelt period when highest water discharges are observed (Iida et al., 2012).

A considerable part of sediments becomes temporarily redeposited immediately after a sharp decline of the river channel gradients where the stream valleys from hills enter the upland depressions. Such areas can be considered as intermittent storage, as sediment were remobilized by bank and bed erosion during extreme flood.

Contemporary denudation rates for the faulting zone rangelands of the Niida River basin is $434 \mathrm{t}$ $\mathrm{km}^{-2} \mathrm{yr}^{-1}$ as estimated from sediment storage in Takanakura Reservoir for 1975-2013 period (based on monitoring data), which even exceeds denudation rate for small catchments of Japanese Alps. Completely forested territory of the rangelands is also dominated by sediment production from small stream bank and bed erosion.

\section{Conclusions}

The detailed assessment of geomorphological impact of the extreme flood in the Niida River basin allows concluding that different exogenic processes (landslides, scree, bank erosion etc.) were the main sediment sources for the river sediment discharge. Maximum channel deformations were observed within the lower reach of the Niida River located on the coastal plain because of extremely high energy of the stream with maximum water and sediment discharges. Morphological type of channel in the lower reach of the Niida river considerably influence on the intensity of erosion and sedimentation processes and on the proportion between them. The most intense transformation of the river channel was observed within the river section with meandering type of channel following by the section of the river with wandering (braided) type of channel. The highest areas of bank erosion (36431 $\mathrm{m}^{2}$ ) and floodplain sedimentation $\left(79499 \mathrm{~m}^{2}\right.$ ) are observed for meandering channels, located in the sub-zone 2, while the highest area of in-channel deposition $\left(19713 \mathrm{~m}^{2}\right)$ is established for the meandering channel in sub-section 3 . The section of the river with straight type of channel was characterized by a relatively low river bottom transformation It was found that bank erosion exceeded in- channel deposition in 1,7-2,7 times for all types of river channel in the low reach located within the coastal floodplain. However, floodplain sedimentation is the most active processes for the river sections with meandering and wandering types of the river channel. Floodplain sedimentation exceed bank-erosion in 2.2 times for river sections with the meandering type of channel and in 2.9 time for the river sections with wandering type of channel. The bank erosion exceeds floodplain deposition in 1,2 times only within the river sections with straight type of channel. Total sedimentation 
(in-channel + floodplain) in 2.6 times higher than bank erosion in the lower reach of the Niida River after extreme flood event $4-5 \%$ probability. However, sedimentation rates on the floodplain of the upper reaches of the Niida River were also one order of magnitude higher than the mean annual rates. The middle reach of the Niida River is an area of active bank and bottom erosion, because of highest river bed gradient. It is also a transit area for the sediment transported by the stream from the upper reach.

\section{Acknowledgements}

Work was funded by RFBR project no. 16-05-00815.

\section{References}

Alabyan AM., Chalov R.S. 1998. Types of river channel patterns and their natural controls. Earth Surface Processes and Landforms 23: 467-474.

Borga M., Stoffel M., Marchi L., Marra F., Jakob M., 2014. Hydrogeomorphic Response to Extreme Rainfall in Headwater Systems: Flash Floods and Debris Flows. J. Hydrol. 518 (part B): 194-205

Chalov R. S. 1996. Types of channel processes and principles of morphodynamic classification for river channels. Geomorfologiya 2: 26-35 (in Russian).

Costa JE. 1988. Rheologic, Geomorphic, and Sedimentologic Differentiation of Water Floods, Hyperconcentrated Flows, and Debris Flows. In: Baker VR, Kochel RC, Patton PC (eds.), Flood Geomorphology. Chichester, John Wiley \& Sons, 113-122.

Eaton B.C., Lapointe M.F. 2001. Effects of large floods on sediment transport and reach morphology in the cobble-bed Sainte Marguerite River. Geomorphology 40: 291-309.

Formann E, Habersack HM, Schober S. 2007. Morphodynamic river processes and techniques for assessment of channel evolution in Alpine gravel bed rivers. Geomorphology 90: 340-355.

Fukuyama T, Takenaka C, Onda Y. 2005. ${ }^{137} \mathrm{Cs}$ loss via soil erosion from a mountainous headwater catchment in central Japan. Science of the Total Environment 350: 238-247.

Fukushima Prefectural Government, Report on Information of Water Area (River) Planning Environmental Standard Zoning, 2007, p. 211
Fuller IC. 2008. Geomorphic impacts of a 100-year flood: Kiwitea Stream, Manawatu catchment, New Zealand. Geomorphology 98(1-2): 84-95.

Gaume E., Borga M. 2008. Post-Flood Field Investigations in Upland Catchments After Major Flash Floods: Proposal of a Methodology and Illustrations. J. Flood Risk Manag. 1(4): 175-189.

Golosov V, Botavin D, Konoplev A, Wakiyama Y. 2016. Geomorphological and radioecological consequences of extreme flood in lowmountainous region of the radioactively contaminated area in subtropical belt (example of Niida River basin, Honshu Island, Japan). Proceedings of the Conference Modern problems of erosion river channel and mouth processes, Arkhangelsk, September 2016, 35-41 (In Russian).

Gomi T, Sidle RC, Miyata S, Kosugi K, Onda Y. 2008. Dynamic runoff connectivity of overland flow on steep forested hillslopes: scale effects and runoff transfer. Water Resources Research 44: W08411. doi:10.1029/2007WR005894.

Hooke J. 2003. Coarse sediment connectivity in river channel systems: a conceptual framework and methodology. Geomorphology 56(1-2): 79-94.

Iida T, Kajihara A, Okubo H, Okajima K. 2012. Effect of seasonal snow cover on suspended sediment runoff in a mountainous catchment. Journal of Hydrology 428-429: 116-128.

JMA (2015) http://www.data.jma.go.jp/obd/ stats/etrn/index.php

Kitamura A, Yamaguchi M, Kurikami H, Yui M, Onishi Y. 2014 Predicting sediment and cesium-137 discharge from catchments in eastern Fukushima. Anthropocene 5: 22-31.

Kochel RC. 1988. Geomorphic impact of large floods: review and new perspectives on magnitude and frequency. In: Baker VR, Kochel RC, Patton PC (eds.), Flood Geomorphology. Chichester, John Wiley \& Sons, 169-187

Konoplev AV, Golosov VN, Yoschenko VI, Nanba K, Onda Y, Takase T, Wakiyama Y. 2016 Vertical Distribution of Radiocesium in Soils of the Area Affected by the Fukushima Dai-ichi Nuclear Power Plant Accident. Eurasian Soil Sciences 49 (5): 570-580.

Kuo C-W, Brierley G, Chang Y-H. 2015. Monitoring channel responses to flood events of low to moderate magnitudes in a bed rock dominated river using morphological budgeting by terrestrial laser scanning. Geomorphology 235: 1-14. DOI:10.1016/j.geomorph.2015.01.019

Miyata S, Kosugi K, Gomi T, Mizuyama, T. 2009. Effects of forest floor coverage on overland flow and soil erosion on hillslopes in Japanese cypress plantation 
forests. Water Resources Research 45: W06402. DOI:10.1029/2008WR007270

Lane SN, Westaway RM, Hicks DM. 2003. Estimation of erosion and deposition volume in a large, gravelbed, braided river using synoptic remote sensing. Earth Surface Processes and Landforms 28: 249-271.

Leopold LB, Wolman LB. 1957. River channel patterns: braided, meandering and straight. U.S. Geological Survey Professional Paper 282-B, U. S. Government Printing Office, Washington, D. C. 85 p.

Marchi L, Borga M, Preciso E, Gaume E. 2010 Characterisation of Selected Extreme Flash Floods in Europe and Implications for Flood Risk Management. J. Hydrol. 394 (1-2): 118-133.

Rădoane M, Perșoiu I, Cristea I, Chiriloaei F. 2013. River channel planform changes based on successive cartographic data. A methodological approach. Revista de Geomorfologie 15: 67-86.

Schumm, S. A. 1985. 'Patterns of alluvial rivers', Annu. Rev. Earth Planet. Sci., 13: 5-27. Surian N, Mao L, Giacomin M, Ziliani L. 2009. Morphological effects of different channel-forming discharges in a gravel- bed river. Earth Surface Processes and Landforms 34(8): 1093-1107.

Thompson C, Croke J. 2013. Geomorphic effects, flood power, and channel competence of a catastrophic flood in confined and unconfined reaches of the upper Lockyer valley, southeast Queensland, Australia. Geomorphology 197: 156-169.

Ueda S, Hasegawa H, Kakiuchi H, Akata N, Ohtsuka Y, Hisamatsu S. 2013. Fluvial discharges of radiocesium from watersheds contaminated by the Fukushima Dai-ichi Nuclear Power Plant accident, Japan. Journal of Environmental Radioactivity 118: 96-104.

Wolman MG, Gerson R.1978. Relative scales of effectiveness of climate in watershed geomorphology. Earth Surface Processes and Landforms 3: 189-208.

Wolman MG, Miller JP. 1960. Magnitude and frequency of forces in geomorphic processes. J. Geol. 68(1): 54-74.

Zanoni L, Gurnell A., Drake N, Surian N. 2008. Island dynamics in a braided river from analysis of historical maps and air photographs. River Research and Applications 24: 1141-1159. 